\title{
Inmar, the Udmurt God, in Modern Udmurt Literature
}

\author{
Aleksey Arzamazov \\ e-mail: arzami@rambler.ru
}

\begin{abstract}
One of the productive directions of research into Udmurt literature (and more broadly other Finno-Ugric 'small' literary traditions) is the identification and interpretation of multidimensional mythological clusters, textual representativeness and semantic ambivalence. In this work I have focused on only one aspect, the functional and semantic field of a particular character in Udmurt mythology and national poetry at the turn of the $21^{\text {st }}$ century. The chosen mythological character is Inmarl God. The study has predominantly focused on ethnic and futuristic poems by Petr Zakharov, Viktor Shibanov, and Anastasiya Shumilova, characterised by a high concentration of mythological symbols. The presented research demonstrates how complex the image of Inmar is for direct artistic understanding.
\end{abstract}

Keywords: Udmurt mythology, Inmar/God, use of Inmar in literature

One of the productive directions of research into Udmurt literature (and more broadly other Finno-Ugric 'small' literary traditions) is the identification and interpretation of multidimensional mythological clusters, textual representativeness and semantic 
ambivalence. These are primarily caused by the stadial-typological nature of the national literature and its internal and external markers of genetic conjugation with the figurative-symbolic universe of traditional culture. The scientific problem of the search for and analysis of mythological roots, i.e. the layers of literature found in the complex consideration of the development of a minority literary system, is already highly relevant, and moreover it should be mandatory, a programmed analytical strategy, the inevitable choice of the scientist. Mythological representations and folklore imagery are a kind of ethno-cultural fundamental principle on the basis of which the author's artistic identity is formed. It is noteworthy that modern Udmurt literary critics, working with written pieces from different historical periods, trends and genres, usually avoid updating scientific issues related to the folklore and mythological beginning of the artistic whole. To date, study of mythological plots, and mythological and folklore paradigms of Udmurt literature have been limited to individual articles, usually the work of one author (Arzamazov 2010; Vanyushev 2004; Vasil'yev, Shibanov 1997; Zaytseva 2006; Il'yina 2006; Shklyayev 2004). The undeveloped nature of this topic is explained, among other things, by its theoretical complexity. Some blurring of the conceptual and categorical apparatus has developed (or is developing) that hinders interpretation and description of the myth in the systems of Udmurt worldview and culture. The appeal of the mythological strata is of great importance in the context of justifying a systematic development of Udmurt literature, as well as in determining the quality and originality of Udmurt writers' interpretation of their ethnic mythology.

In a global sense, we can talk about identifying the features of an author's 'experience' of mythological matrices in typologically related and unrelated literatures, and about building scientifically reasoned comparative collations.

The mythological expressiveness of Udmurt literature and poetry (depending on the rhetoric of the era), which determines the artistic priorities and semantic centres, had a different qual- 
ity of presentation in the written work. Great attention was given to traditional culture by the poet and educator Kuzebay Gerd, for example in his poems. Here we see many mythological contexts and subtexts, and when the characters of Udmurt mythology appear they receive the sufficiently broad dissemination of folk images. Within socialist realism, which for many decades set the themes and determined the artistic and plot pragmatics of national literature, the open mythological hypertexts that go back to the traditional worldview of the Udmurt, were unacceptable. They would have been perceived as an alternative to the Soviet model of the world, as a mentally dangerous symbolic reality. In the conditions of significant ideological and communicative limitations that the Soviet era presented there was a replacement of one system of values and ideas with another. The original Udmurt figurative and symbolic codes were subject to displacement by the socialist emblematic. We can also talk about the emergence of the author's ideologised 'double bottom' texts that have references to ethnos or language and which, despite the strict and artificial external regulations, somehow manifest themselves and translate their semantics.

In the years of perestroika there was a rapid renewal of artistic interests with an inevitable revision of the themes, objectives and concepts of national culture. The undeveloped mythological heritage of the people, the symbolic potency of folklore became a more and more creative attraction. In the early 1990s, the cultural life of Udmurtia saw the rise of ethno-futurism, a complex modernisation phenomenon that played a key role in the history of Udmurt literature and art. In ethno-futuristically oriented works, a significant place is given to mythology, which is perceived not so much as a heterogeneous worldview but more as a source of new imagery, symbolic depiction. The semiotic reality of many written pieces from the post-Soviet period suggests that the national writers' understanding of the subtle matters of the religious and mythological picture of the Udmurt world is incomplete and fragmentary. Decades of ideological press cut off the ethno-forum from 
the cultural resources of its people. However, the artistic need for this own yet foreign, not yet acquired language of writing, is notorious. The natural tendency of Udmurt artists to work with mythology and folklore material, including mechanisms of cultural memory, seems to be natural. In the framework of ethnic futurism a specific multi-level mythological discourse developed within art that saw worlds opposed to each other form a sort of single whole, a world of nature and the urban daily routine, paganism, atheism and Orthodox Christianity. It was psychologically interactive, with a sense of ethnic liberation and socio-political awareness of bitterness and a deep sense of being creatively unrealised. Multifaceted mental-social transformations, experienced by the Udmurt people, could not be better reflected in these mythological re-glued mirrors of ethnic futurism, where each shard of glass shows its own picture, its own event.

Realising the scale of the analytical problem of considering the mythological plan of Udmurt literature, in this work we have focused on only one aspect, the functional and semantic field of a particular character from Udmurt mythology in the Udmurt poetry at the turn of the $21^{\text {st }}$ century. Our choice, among other things, was dictated by the relative simplicity of the object of study, the outline of the artistic search area. In the structure of poetic texts the chosen mythological character - Inmar/God - is almost always in sight. It was assumed that his in-text position is usually complicated by the author's point of view. Our study has predominantly focused on ethnic and futuristic poems by Petr Zakharov, Viktor Shibanov and Anastasiya Shumilova, characterised by a high concentration of mythological symbols.

Considering the mythological personages of Udmurt poetic works, it is necessary to produce a list of characters that authors would use, and at the same time could be found in the spiritual and ideological foundations of the Udmurt ethnic group. These criteria produce a number of images, subjects, 'beings' that show varying degrees of meaningful and functional complexity and relatedness 
to the realities of world religions (Inmar, Kyldys'in, Shaytan, Keremet, N'ulesmurt, Vukuz'o/Vumurt, Vunyl, Palesmurt, Ishan, Albasty, Vozho). Accordingly, the list of 'heroes' in the study can be continued, and the very formulation of the problem and scale of its scientific solution, suggest comprehensive multilateral analytical work, the results of which go far beyond a single scientific article.

The first in the hierarchical system and one of the most ambiguous from the point of view of artistic conceptualisation of symbols is Inmar/God (see Vladykina, Glukhova 2011: 69).

The mythological character Inmar as an image in the poetry of Pyotr Zakharov has high indices of use, i.e. it is in high demand. However, the symbol under consideration does not always fit well into a lyrical story, and does not necessarily have an independent artistic function. The analysis of a large corpus of texts showed that the semantic load of Inmar in the structure of Zakharov's poems is rarely motivated by mythological representations of the Udmurt ethnic group. In his debut, and most voluminous collection of poems, Vozh vyzh ('The Green Bridge', 2001) the symbol of Inmar appears more than 30 times, which shows the great potential 'operationality' of this concept in this specific style. Nevertheless, the prevailing scenario emphasises the real poetic role of Inmar in the author's text, the facets of its existence and the minimum, peripheral connectedness with the semantic centre of the work. Mention of Inmar in a number of Zakharov's texts is often part of a statement about a lyrical subject, a component of speech that expresses a certain set of socially conditioned feelings, a lexical echo of a complex psychological state, a pensive and dreamy immersion in oneself:

"Inmar ponna ud s'oty-a mynym? ('For God's sake, will you give me?');

"Okh, Inmare, - kure Isay, - / tynyd mon van'ze s'otysal, / Puzhyosse soles' ke tshupasal...” ('Oh, my God, says Isai, I 
I would give you everything, / If I'd have kissed her freckles...');

“Okh, Inmare, kytshe mözmyt...” ('Oh, my God, how sad...’);

“Peymyt mynym, ton us'ty val öste, / Kot'yugdy val ton, oste Inmare..." ('I'm in the dark, open the door / At least, give the light, my God').

The fixed frequency of use of the name Inmar, in all probability, is due to subconscious compensatory factors relating to God, with especially obvious pagan mythological outlines which during the Soviet period were impossible to mention let alone give a creatively conscious response. After perestroika, in the 1990s, this important word in Udmurt intellectual culture became not just regular in literary, journalistic national discourses but also one of the dominants of everyday communication and colloquial speech, often unburdened by any significant spiritual or mental pragmatics.

The word Inmar in Zakharov's work can be semantically integrated into a meaningful artistic context in which the author prescribes its truths and defends his existential position, opposing the position of another. In a poem entitled "Kabakyn todmatskon" ('Meeting in a Pub'), a lyrical 'me' declares that poetry for him is Inmar, God, thus pointing out his distinguished status to his collocutor. The belittling of the lyric 'you' follows:

Mon ponna poeziya Inmar, For me, poetry is Inmar (God), Ton ponna ug todis'ky For you, I don't know what mon mar I am

(Zakharov 2001: 124)

This poem reflects Zakharov's favourite aphorism: that poetry is the quintessence of culture, art, literature, etc., and that the poet 
has a special relationship with God. The poet him- or herself is allowed to be a demiurge, creating his or her own universe in the literary word. The lyrical subject compares himself with Inmar in the poem “Töd'y kagaz” ('White Paper'). Here he talks again about the divine beginning of creation, creativity.

Mynam az'am töd'y-töd' kagaz,

Ogpol no kutymte no isamte no na so.

Inmar kad' pukis'ko solen $a z^{\prime} a z$,

Nosh no utshke. Vit'e.

Dun'n'e tuso...

(Zakharov 2001: 48)
Before me there is white white paper,

Never held, never touched.

Like Inmar, I'm sitting in front of it.

And it is watching...

Waiting...

It features the guise of the world...

The name Inmar in Zakharov's book Vozh vyzh can be contextually associated with artistically playing with social issues. The main body of poems included in this collection was written in the $1990^{\mathrm{s}}$ and was permeated with the drama of experiencing the new time and the new rules of the social games. In Nunal pörat ('Every Day') (Zakharov 2001: 75) the post-Soviet era is associated with the inevitability of atonement for socialist deceptions and illusions. In the nineties people sacrifice themselves to Inmar and human blood flowed (the motif of blood shed by the people is also found in the poetry of Mikhail Fedotov, whose lyrical hero perceives the new era in a passive way).

One of the most common subjects in Zakharov's poems is a dispute with himself about the existence of God. Doubts are often marked with a 'hob-and-nob' intonation of appealing to the Almighty: 
Van'-a ton, övöl-a ton,

Inmar?

Van'ke, bas'ty, tan'i so

luly...

(Zakharov 2001: 45)

Van'-a ton, Inmare? - mon

shuo.

Van'-a ton? - mon shuo,

Inmare.

Van'ton, van'ton! - achim

ik shuo.

Van' ton, van'ton! - shuo

Inmare.

(Zakharov 2001: 94)
Do you exist, do you not, Inmar?

If you exist, here is this soul, take it...
Do you exist, my Inmar? - shall I say.

Do you exist? - I shall say, my Inmar.

You exist, you exist! - I shall say myself.

You exist, you exist! - I shall say, my Inmar.

Such rhetorical combinations and cognitive reactions are, apparently, the projection of the 'open' consciousness of the post-Soviet Udmurt ethno-forum, existing in the mode of a multi-directional perception of the world, standing at the crossroads of atheism, Orthodox Christianity and traditional belief. Udmurt culture's understanding of its unreadiness for the new realities of the turn of the century is superimposed on this complex internal state of self-determination.

In the poem Uysyos ('Owls') Inmar is called to witness the lovingly erotic mutual learning of a village boy and girl, whose unity is shown in the lyrical 'me' as an important life event, and as another, new, face of sin: Ekh, kytshe busas'ko ta uyyos! / / Med addzh'oz n’i, addzh'oz ke Inmar... / Med luozn’i, luoz ke koshmar... / Mi gine shat sytshe s'ölykoyes'... (“Oh, how foggy were those nights!/Let him see already, if Inmar sees,/Let it be already, if there is a nightmare./Are only we such sinners?" (Zakharov 2001: 24). On the compositional level, the poem Adzh'yli val, s'in "yosyd tynad ('I Saw Your Eyes...'), is a lyrical monologue by a man who persuades a girl in love with 
him to forget him. He asks her to erase him from her memory and her heart, and not to ask Inmar about him:

Ogshory mon ul'chays'

shpana-

Vamyshly byde vuzas'kis'ko

Inmarez en kure mon

ponna,

Ton soku achid s'ölykas'kod
I'm an ordinary street rabble

For sale at every step

Do not ask Inmar for me

Then you yourself will become a sinner

(Zakharov 2001: 79).

Again, Inmar is narratively manifested in the possibility of sin.

In the lovingly playful poem Dzh'ol'gyri so dzh'ol'gyri ('The Sparrow is a Sparrow') the mood of the beloved is expressed using floral, ornithomorphic characters. Within the framework of this association the pine is a cold Inmar. Apparently, this parallel emphasises inaccessibility, the cold detachment of the favoured one.

Notably, among the many poems in the collection the Udmurt Inmar (inmaryos, inmars, gods) is mentioned only once. This mythological character is generally characterised by a weak correlation with the semantic core of the poem. His appearance is in parallel to the development of the love story and brings a semantic shade, the divine symbolism or fatal predetermination of the feeling of love:

As'meos kyldytemyn parly: We're made to be a couple:

Kyknamy uk yug-yug chukdores'. We're both fair-haired, white-

Vashkala udmurt maned.

inmar"yosly

Par val"yos luo val The ancient Udmurt gods

yarys'es'...

Needed a couple of decent

(Zakharov 2001: 132) 
In Vozh vyzh, the phrase Inmar yurtte! ('Inmar helps') is used once. At the same time, God's help is presented as a phenomenon from the lives of others: Yaram in'i, Inmar, shuo, yurtte" ('Well, at least Inmar, they say, helps').

Inmar is one of the hypostases of the corporeality of the lyrical 'me':

Nosh mugory, ben, mugory, Napchem omyr so ogshory...

Achiz inmar, achiz ishan Achiz kötdzhozh, achiz veshan -

Pöyas'konen suro zemlyk

Kudiz ug s'oty buyganlyk... (Zakharov 2001: 176)
And my body, yes, my body, The thickened air is just it...

It is Inmar, it is Ishan, It is the very grief, it is affection, The truth mixed with deception That does not give rest...

In the second poetic collection, Karas (Honeycombs), by Petr Zakharov, the word image Inmar, despite the general mythological orientation of most poems, is presented fragmentarily, weakly associated with the traditional culture of the Udmurt people. It should be noted that Karas is a curious linguistic and artistic experiment in which Udmurt poems are accompanied by Russianlanguage substrings, often not very accurately made. Individual texts in the collection in terms of their meaning look dark, difficult to easily apprehend or interpret. This category of poem includes Kytyn övöl kuara ('Where There Is No Voice') (Zakharov 2010: 18-19). The attraction to the image of Inmar here is poorly motivated, reflecting the general artistic ambiguity of the author's idea. Inmar is probably actualised in connection with the metatheme of the imperfections of human life, receiving development in Karas, 
through which the main message of losses and disappointments is delivered.

The poem Kuke siz'o dzhökkyshetles' s'ures ('When They Wish You Good Riddance!') is interesting for its artistic reconstruction of the semantics of the image of Inmar (Zakharov 2010: 24-25). The text is also notable for the errors in Russian translation: "Kogda nas shlyut po skaterchnoy dorozhke, pripomnyu, chto nash zad krasivshe pereda". It seems that there was a language failure when preparing the Russian version: the poet seems to forget about the basic rules of word usage, violates the laws of Russian grammar, and significantly distorts the lexemes.

Such sudden powerlessness before the Russian language is apparently connected with the author's actualisation in the first lines of the poem in its Udmurt phraseological construction. Initially, the original meaning of the phraseology used (the requirement to leave, to get away) is semantically complicated by deep ideological confrontations. The artistic and meaningful 'struggle' between the Udmurt and the Russian languages correlates in the plot with the juxtaposition of the Christian Orthodox God and Pagan Udmurt Inmar. The 'darkened' poem, abundant in changes in the author's thoughts, continues the topic of the interaction/mutual repulsion of Udmurt and Russian cultures, which is important and productive for Zakharov because it accentuates the complexity of events in the mind of a priori ethno-forum mythological units and the Christian worldview. In 'When They Wish You Good Riddance!' the multiplicative reality of the worldview of the Udmurt individual can be felt as the phraseology of traditional beliefs merges with the desire of the author's 'me' to use Christian philosophical generalisations and conclusions such as the designation of human sinfulness and the inevitability of punishment.

Another option for the mixing of poetry and mythology is present in the sixth poem of Zakharov's Udmurt tunolen kyrdzhan"yosyz ('Songs of the Udmurt Shaman') cycle (Zakharov 2010: 42-43). 
The Udmurt gods Inmar and Kuaz', who give the lyrical hero secret knowledge, are narratively and contextually associated with the Sumerian/Akkadian Marduk. In his literary work, Zakharov often reduces heterogeneous mythological characters to subjects of culture, thereby intuitively emphasising antiquity and Nostratic nature as well as the civilisational 'competitiveness' of the traditional Udmurt worldview and folklore, and the artistic openness of its literature.

Inmar appears in the Utopian urban poem "Uzy-bory kis'ma val gorodyn..." ('Strawberries Ripe in the City...'). The space of the city is occupied by insects and worms, busy with affairs that are absurd and useless from the human point of view. Apparently by using such a comparison the poet parodies the life of the modern citizens of Izhevsk. In the poem, Inmar becomes a passenger on the tram, the route of which is the sky, the night, light, symbolically named Uruguay:

Kuar"yos ulys' taka-baka s'örys'

Potiz zor-papaly ukshas' tramvay

Inbam ulti gyldzh’iz so

kyrdzh'asa

So yardure, kytyn val

Urugvay.

Nosh tramvayyn pishtis'

kylbur"yosyn

Myniz Inmar, udmurt

kad', kunoye.

Kiz'il'ios mynda ik

tyl'yosyn

Salam nuiz so kyd'okys'

uye...

(Zakharov 2010: 124-125)
From under the leaves, from behind the shell

Out came a ladybird-like tram,

And it slipped with a song through the sky,

Onto the shores where Uruguay was.

And in the tram in the shape of bright poems

Inmar went on a visit like an Udmurt.

In innumerable lights, as

stars

He was carrying presents into those distant nights... 
It is no coincidence that Inmar is associated with poetry in this poem. For Zakharov, poetry is equivalent to God, life, love; its nature is magical, conjuring, sacred.

In Zakharov's third collection of poems, Kyrmush ('Wild bee') (Zakharov 2015), Inmar neither appears often, nor is he artistically significant. The content of this book suggests that Zakharov's poetry has changed direction towards a deeper discussion of social issues and coverage of recent Udmurt history. The mythological symbolism at this poetic turn remains unclaimed.

Inmar - a symbol of borderline semantics that combines pagan and Christian ideas about God - is very rare in the poems of Viktor Shibanov, one of the main ideologists of the ethno-futurist trend. Shibanov regularly refers to mythological characters of a "second row" that does not usually correspond to Christian or Orthodox contexts. In his debut book Vyl' uzh"osy öt'o ('From Case to Case') (Shibanov 1982), the mythological characters do not exist due to the internal and external constraints of social realism. In his Bertis'ko uyshore ('I am going back to Midnight') (Shibanov 1991) a whole gallery of mythological subjects is presented, among which there is no place for Inmar. Inmar does, however, appear in several texts in Shibanov's Ös ('Door') (Shibanov 2003), although his artistic functioning is minimised as a whole. In the sixth and seventh poems of the Yöl kis'tis'kem ('The Milk Spilled') cycle Inmar acts in a unified semantic context with Keremet, which embodies the evil principle of the universe. At the same time, the author's attention is more focused on the negative character with whom the lyrical 'me' enters into dialogue. The author perceives the opposition of Inmar and Keremet as an irrefutable existential reality, an axiological inevitability. The reciprocity of Inmar and Keremet is iconic - a person rejected by Inmar may not be protected by Keremet: 
Soin ik kot'ku Inmaren arte

Med keremet syloz.

Mynam soin

Kuddyr s'ulmys'

veras'keme pote.

So vaz'ysal: "Vordskid

bere uin,

Uyyn ik ul no buygat

esh"yoste".

"Soos van'zy in'i uzyr".

Nosh kin

Dan"ya tshukez addzh'ylytek,

So ush"yamon ke no, urod poet.

So vatsasal: "Kushtiz bere inmar

Mynam no yurtteme tynyd ug lu.

Gerdzh'as'kemyn mimur vyzhy no kuar

Nish ogaz'yn

kyldytis'kom: pispu.

Modos nachar bere, soku nachar

S’öd dun'n'eys' vyzhyosyd.
So always next to Inmar

Let Keremet stand.

I sincerely

Sometimes want to talk to him.

He'd say: "Just as you were born in the night, Live at night and calm your friends."

"They're all rich already."

"And who

Glorifies the morning, morning not seeing,

Although it is commendable, is a bad poet."

He would add: "If Inmar left you,

And I can't help you.

Connected, we're a deep root and a leaf,

And together we form a tree.

Once the trunk is weak, so weak

Your roots are in this black world."

(Shibanov 2003: 34-35)

Inmar in the poems of Anastasiya Shumilova, who represents the younger generation of Udmurt poets, occupies a very modest place. The new generation of national writers is far from both the 
religious and mythological foundations of the Udmurt world, and from any religion in general. Something of which the artistic existence of Udmurt mythological characters in Shumilova's creative discourse is indicative. Thus, Inmar ceases to be the centre of the universe and loses his sacred significance; as he comes to obey the desires and actions of the lyrical 'me', he is mortal and debased.

The presented study shows how complex the image of Inmar is to those who wish through art to understand its usage. Despite using Inmar frequently, Udmurt poets failed to create meaningful semantic contexts for the poetic use of Inmar; for example, mythological resources were not used and the system of Christian Orthodox representations was not fully activated.

\section{References}

Arzamazov, A. 2010. Fenomen vizual'nogo v sovremennoy udmurtskoy poezii (opyt analiza tvorchestva P. M. Zakharova) [The Phenomenon of the Visual in Modern Udmurt Poetry (Analysis of P. M. Zakharov's Poetry)]. Izhevsk: Udmurtskiy institut istorii, yazyka i literatury Uralskogo otdeleniya Rossiyskoy akademii nauk; Udmurtskiy universitet.

Il'yina, N. 2006. Khudozhestvennyy mifologizm besermyanskogo poeta M. Fedotova v kontekste udmurtskoy literatury 1980-1990 gg.: Kand. Diss. [Poetic Mythology of the Beserman Poet M. Fedotov in the Context of Udmurt Literature of the $1980^{\mathrm{s}}-1990^{\mathrm{s}}$ : PhD Thesis]. Cheboksary: Cheboksary Universtitet.

Shibanov, V. 2003. Ös: kylbur"yos [The Door: Poems]. Izhevsk: Invozho.

Shibanov V., Vasil'yev, S. 1997. Pod ten'yu zerpala: diskursivnost', samosoznaniye $i$ logika istorii udmurtov [In the Shadow of Zerpal: Discursivity, Identity and the Logic of History of Udmurts]. Izhevsk: Udmurtia. Vol. 1.

Shklyayev, A. 2004. Literatura mifa i mify o literature: o nekotorykh formakh vzaimootnosheniy literatury i mifa [Literature of Myth and Myths about Literature: About Some Models of Relations between Literature and Myth]. In: Udmurtskaya mifologiya [Udmurt Mythology]. Izhevsk: Udmurtskiy institut istorii, yazyka i literatury Uralskogo otdeleniya Rossiyskoy akademii nauk, pp. 171-177. 
Vanyushev, V. 2004. Mifologicheskiye syuzhety i obrazy v udmurtskoy poezii. [Mythological Plots and Images in Udmurt Poetry]. In: Udmurtskaya mifologiya [Udmurt Mythology]. Izhevsk: Udmurtskiy institut istorii, yazyka i literatury Uralskogo otdeleniya Rossiyskoy akademii nauk, pp. 159-170.

Vladykina, T., Glukhova, G. 2011. Ar-god-bergan: Obryady i prazdniki udmurtskogo kalendarya [Year Circulation: Rituals and Celebrations of the Udmurt Calendar]. Izhevsk: Udmurtskiy institut istorii, yazyka i literatury Uralskogo otdeleniya Rossiyskoy akademii nauk.

Zaytseva, T. 2006. Proza Nikvlada Samsonova: mifopoeticheskaya obraznost' [The Prose by Nikvlad Samsonov: The Mythopoetic Imagery]. In: Sovremennaya udmurtskaya proza (1980-2000-e gody) [Modern Udmurt Prose $\left(1980^{s}-2000^{\mathrm{s}}\right]$. Izhevsk: Udmurtskiy universitet, pp. 25-56.

Zakharov, P. 2001. Vozh vyzh = Zelenyy most: stikhi, poemy, perevody [The Green Bridge: Poems, Long Poems, Translations]. Izhevsk: Invozho.

Zakharov, P. 2010. Karas = Soty: pesni udmurtskogo shamana [Honeycombs: Songs of the Udmurt Shaman]. Izhevsk: Invozho.

Zueva-Izmaylova, A. 1997. Udmurtskaya literatura $v$ kontekste yazycheskikh $i$ khristianskikh traditsiy [Udmurt Literature within the Context of Pagan and Christian Traditions: A Monograph]. Izhevsk: Udmurtskiy universitet.

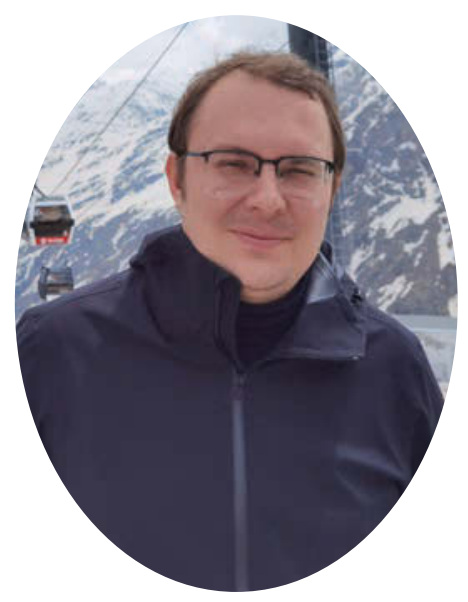

Aleksey Arzamazov ( $\mathrm{PhD}$ hab) is a professor, leader of the laboratory of multifactorial analysis and cognitive philology at the FRC Kazan Scientific Center, Russian Academy of Sciences. He is a specialist in literature in general and Udmurt modern literature in particular.

e-mail: arzami@rambler.ru 